\title{
MEDIA ULAR TANGGA JEJAK PETUALANG SEBAGAI MEDIA PEMBELAJARAN UNTUK ANAK USIA DINI
}

\author{
Ria Kurniasih ${ }^{1}$
}

\begin{abstract}
ABSTRAK
Proses belajar mengajar merupakan suatu kegiatan untuk melaksanakan kurikulum dalam lembaga pendidikan, agar dapat mempengaruhi para siswa mencapai tujuan pendidikan yang telah ditetapkan. Salah satu unsur yang sangat penting dalam proses belajar mengajar adalah media pembelajaran. Media pembelajaran adalah suatu perantara yang digunakan oleh pendidik/guru untuk menyalurkan pesan atau informasi kepada siswanya sehingga siswa tersebut dapat terangsang ketika mengikuti kegiatan pembelajaran. Dapat dikatakan pula media pembelajaran dapat memudahkan siswa untuk menerima pembelajaran yang disampaikan pendidik/guru. Media pembelajaran terlebih dahulu telah dikenal sebagai alat bantu dalam pembelajaran yang seharusnya dimanfaatkan para guru, namun seringkali terabaikan. Salah satu contoh media yang interaktif, kreatif dan edukatif untuk usia anak dini yaitu media permainan Ular Tangga "Jejak Petualang". Permainan ular tangga adalah salah satu jenis permainan tradisional yang mendunia. Permainan ini merupakan jenis permainan kelompok, melibatkan beberapa orang dan tidak dapat digunakan secara individu. Media pembelajaran dengan menggunakan permainan ular tangga ini terdiri dari 4 bagian yaitu; kertas petak permainan, kartu pertanyaan, dadu dan maskot. Untuk membuat media ular tangga "Jejak Petualang" sangatlah sederhana sama seperti jenis permainan ular tangga lainnya. Hanya saja kita sebagai guru harus memodifikasi sedemikian rupa seperti apa yang kita inginkan untuk mencapai tujuan pembelajaran. Permainan ular tangga "Jejak Petualang" digunakan untuk penciptaan suasana belajar dari pasif ke aktif, dari kaku menjadi gerak (akrab), dan dari jenuh menjadi riang (segar). Media ini diarahkan agar tujuan belajar dapat dicapai secara efisien dan efektif dalam suasana gembira meskipun membahas hal-hal yang sulit atau berat.

Kata Kunci : Media pembelajaran, ular tangga "Jejak Petualang"
\end{abstract}

\section{A. PENDAHULUAN}

Proses belajar mengajar merupakan suatu kegiatan untuk melaksanakan kurikulum dalam lembaga pendidikan, agar dapat mempengaruhi para siswa mencapai tujuan pendidikan yang telah ditetapkan. Tujuan pendidikan pada dasarnya mengantarkan para siswa menuju perubahan tingkah laku baik intelektual, moral, atau sosial agar dapat hidup mandiri sebagai individu dan makhluk sosial.

Dalam proses belajar mengajar, dua unsur yang sangat penting adalah metode mengajar dan media pembelajaran. Kedua unsur ini sangat berkaitan, penentuan metode mengajar akan mempengaruhi media pembelajaran yang digunakan, meskipun masih banyak hal yang harus diperhatikan dalam memilih media, seperti tujuan pembelajaran, materi pembelajaran, dan karakteristik siswa.

\footnotetext{
${ }^{1}$ Mahasiswa Sekolah Pascasarjana UPI
} 
Metode pembelajaran adalah suatu cara atau upaya yang dilakukan oleh para guru agar proses belajar mengajar tercapai sesuai dengan tujuan. Sedangkan media pembelajaran adalah segala sesuatu yang dapat digunakan untuk menyalurkan pesan dari pengirim ke penerima.

Media pembelajaran terlebih dahulu telah dikenal sebagai alat bantu dalam pembelajaran yang seharusnya dimanfaatkan para guru, namun seringkali terabaikan. Tidak dimanfaatkannya media pembelajaran, seringkali dikarenakan oleh berbagai macam alasan, misalnya sulitnya mencari media yang tepat, kurangnya pengetahuan guru mengenai penggunaan media, biaya yang tidak ada untuk pengadaan media, waktu persediaan mengajar terbatas atau alasan lainnya. Hal tersebut tidak akan muncul jika para guru/ pengajar tidak memahami pentingnya media pembelajaran.

Berdasarkan latar belakang di atas, melalui makalah ini penulis akan memaparkan materi mengenai media pembelajaran. Tujuan dari pembuatan makalah ini adalah untuk mengetahui:

1. Pengertian media pembelajaran.

2. Kedudukan media dalam sistem pembelajaran.

3. Fungsi media pembelajaran.

4. Manfaat Media pembelajaran.

5. Landasan teoritis penggunaan media dalam pembelajaran.

6. Hal-hal yang perlu diperhatikan dalam pemilihan media pembelajaran khususnya untuk usia dini.

7. Jenis-jenis media pembelajaran untuk usia dini.

8. Penggunaan media ular tangga jejak petualang untuk anak usia dini.

\section{B. PEMBAHASAN}

\section{Hakikat Pengertian Media Pembelajaran}

Kata media berasal dari bahasa latin yaitu medius yang secara harfiah berarti "tengah", "perantara", atau "pengantar". Banyak batasan yang diberikan orang tentang media. Asosiasi teknologi dan komunikasi pendidikan (Association of Education and Communication Technology/AECT) di Amerika, membatasi media sebagai segala bentuk dan saluran yang digunakan orang untuk menyalurkan pesan atau informasi. Menurut Heinich (Susilana dan Riyana, 2009: 6) media merupakan alat saluran komunikasi. Berikutnya menurut Gagne (Susilana dan Riyana, 2009: 6) media merupakan berbagai jenis komponen dalam lingkungan siswa yang dapat merangsang siswa untuk belajar.

Dari beberapa definisi tersebut dapat disimpulkan mengenai pengertian media pembelajaran. Media pembelajaran adalah suatu perantara yang digunakan oleh pendidik/guru untuk menyalurkan pesan atau informasi kepada siswanya sehingga siswa tersebut dapat terangsang ketika mengikuti kegiatan pembelajaran. Dapat dikatakan pula media pembelajaran dapat memudahkan siswa untuk menerima pembelajaran yang disampaikan pendidik/guru.

Pembelajaran adalah suatu sistem yang mempunyai komponen-komponen seperti bahan pelajaran, kegiatan belajar mengajar, sumber dan media, serta evaluasi. Kedudukan media sama pentingnya dengan dengan komponen yang lain yang 
mendukung terbentuknya tujuan pembelajaran. Karena metode yang digunakan dalam proses pembelajaran biasanya akan menuntut media apa yang dapat diintegrasikan dan diadaptasikan dengan kondisi yang dihadapi.

Menurut Levie dan Lentz (Kustandi dan Sutjipto, 2011: 21) mengemukakan empat fungsi media pembelajaran, khususnya media visual, yaitu:

a. Fungsi atensi

Fungsi atensi media visual merupakan inti, yaitu menarik dan mengarahkan perhatian siswa untuk berkonsentrasi kepada isi pelajaran yang berkaitan dengan makna visual yang ditampilkan atau menyertai teks materi pelajaran.

\section{b. Fungsi afektif}

Media visual dapat terlihat dari tingkat kenikmatan siswa ketika belajar (atau membaca) teks yang bergambar. Gambar atau lambang visual dapat menggugah emosi dan sikap siswa, misalnya informasi yang menyangkut masalah sosial atau ras.

\section{c. Fungsi kognitif}

Fungsi kognitif media visual terlihat dari temuan-temuan penelitian yang mengungkapkan bahwa lambang visual atau gambar memperlancar pencapaiaan tujuan untuk memahami dan mengingat informasi atau pesan yang terkandung dalam gambar.

\section{d. Fungsi kompensators}

Fungsi kompensatoris media pembelajaran terlihat dari hasil penelitian bahwa media visual yang memberikan konteks untuk memahami teks membantu siswa yang lemah dalam membaca untuk mengorganisasikan informasi dalam teks dan mengingatnya kembali. Dengan kata lain, media pembelajaran berfungsi untuk mengakomodasikan siswa yang lemah dan lambat menerima dan memahami isi pelajaran yang disajikan dengan teks atau disajikan secara verbal.

Perolehan pengetahuan akan semakin abstrak apabila pesan hanya disampaikan secara verbal. Hal ini akan memungkinkan terjadinya verbalisme, artinya siswa hanya akan mengetahui tentang kata-kata tanpa mengetahui makna yang terkandung di dalamnya. Hal tersebut akan menimbulkan kesalahan persepsi terhadap siswa. Oleh karena itu, sebaiknya siswa mengalami pengalaman yang lebih konkrit, pesan yang ngin disampaikan dapat mencapai sasaran dan tujuan.

Secara umum media mempunyai kegunaan:

a. Memperjelas pesan agar tidak terlalu verbalistis.

b. Mengatasi keterbatasan ruang, waktu tenaga dan daya indera.

c. Menimbulkan gairah belajar, interaksi lebih langsung antara siswa dengan sumber belajar.

d. Memungkinkan anak belajar mandiri sesuai dengan bakat dan kemampuan visual, auditori, dan kinestetiknya.

e. Memberi rangsangan yang sama, mempersamakan pengalaman dan menimbulkan persepsi yang sama. 
Berikut ini merupakan landasan teoritis penggunaan media dalam pembelajaran menurut para ahli.

Pertama, Jerome Bruner, mengemukakan bahwa dalam proses pembelajaran hendaknya menggunakan urutan dari belajar dengan gambaran atau film (iconic representation of experiment) kemudian ke belajar dengan simbol, yaitu menggunakan kata-kata (symbolic representation). Menurut Bruner, hal ini juga berlaku tidak hanya untuk anak tetapi juga untuk orang dewasa (Susilana dan Riyana, 2009)

Kedua, Edgar Dale, membuat jenjang konkrit-abstrak dengan dimulai dari siswa yang berpartisipasi dalam pengalaman nyata, kemudian menuju siswa sebagai pengamat kejadian nyata, dilanjutkan ke siswa sebagai pengamat terhadap kejadian yang disajikan dengan media, dan terakhir siswa sebagai pengamat kejadian yang disajikan dengan simbol dewasa. Salah satu gambaran yang paling banyak digunakan acuan sebagai landasan teori penggunaan media dalam pembelajaran adalah kerucut pengalaman Dale (Dale's Cone of Experience) (Susilana dan Riyana, 2009).

Hal-hal yang Perlu Diperhatikan dalam Pemilihan Media Pembelajaran khususnya untuk Anak Usia Dini

a. Memahami karakteristik media pembelajaran.

b. Sesuai dengan tujuan yang hendak dicapai.

c. Sesuai dengan metode pengajaran yang kita gunakan.

d. Sesuai dengan materi yang kita komunikasikan.

e. Difungsikan untuk mengembangkan berbagai perkembangan anak usia dini.

f. Sesuai dengan situasi dan kondisi lingkungan, kemudahan memperoleh media.

g. Sesuai keterampilan guru dalam menggunakannya.

h. Ketersediaan waktu dalam menggunakannya.

i. Sesuai dengan taraf berpikir siswa.

Jenis-jenis Media Pembelajaran untuk Anak Usia Dini adalah sebagai berikut.

\section{a. Media Visual}

Media visual adalah media yang hanya dapat dilihat. Jenis media visual ini nampaknya yang paling sering digunakan oleh guru pada lembaga pendidikan anak usia dini untuk membantu menyampaikan isi dari tema pendidikan yang sedang dipelajari.

\section{b. Media Audio}

Media audio adalah media yang mengandung pesan dalam bentuk auditif (hanya dapat didengar) yang dapat merangsang pikiran, perasaan, perhatian, dan kemauan anak untuk mempelajari isi tema. Contoh media audio yaitu program kaset suara dan program radio. Penggunaan media audio dalam kegiatan pendidikan untuk anak usia dini pada umumnya untuk melatih keterampilan yang berhubungan dengan aspek-aspek keterampilan mendengarkan. Dari sifatnya yang auditif, media ini mengandung kelemahan yang harus diatasi dengan cara memanfaatkan media lainnya. 


\section{c. Media Audio Visual}

Sesuai dengan namanya, media ini merupakan kombinasi dari media audio dan media visual atau biasa disebut media pandang-dengar. Dengan menggunakan media audio-visual ini maka penyajian isi tema kepada anak akan semakin lengkap dan optimal. Selain itu media ini dalam batas-batas tertentu dapat juga menggantikan peran dan tugas guru. Dalam hal ini guru tidak selalu berperan sebagai penyampai materi, karena penyajian materi bisa diganti oleh media. Peran guru bisa beralih menjadi fasilitator belajar yaitu memberikan kemudahan bagi

anak untuk belajar. Contoh dari media audio visual ini di antaranya program televisi/video pendidikan/instruksional, program slide suara, dsb.

\section{Penggunaan Media Ular Tangga "Jejak Petualang" untuk Anak Usia Dini}

Salah satu contoh media yang interaktif, kreatif dan edukatif untuk anak usia dini yaitu media permainan Ular Tangga "Jejak Petualang". Permainan ular tangga adalah salah satu jenis permainan tradisional yang mendunia. Permainan ini merupakan jenis permainan kelompok, melibatkan beberapa orang dan tidak dapat digunakan secara individu. Media pembelajaran dengan menggunakan permainan ular tangga ini terdiri dari 4 bagian yaitu; kertas petak permainan, kartu pertanyaan, dadu dan maskot.

Adapun pengertian media ular tangga "Jejak Petualang" adalah media ular tangga yang menceritakan tentang petualangan seorang tokoh kartun yang digemari oleh anak, misalnya Dora, Ninja Hatori dan lain sebagainya. Untuk membuat media ular tangga "Jejak Petualang" sangatlah sederhana sama seperti jenis permainan ular tangga lainnya. Hanya saja kita sebagai guru harus memodifikasi sedemikian rupa seperti apa yang kita inginkan untuk mencapai tujuan pembelajaran.

Permainan digunakan untuk penciptaan suasana belajar dari pasif ke aktif, dari kaku menjadi gerak (akrab), dan dari jenuh menjadi riang (segar). Media ini diarahkan agar tujuan belajar dapat dicapai secara efisien dan efektif dalam suasana gembira meskipun membahas hal-hal yang sulit atau berat.

Berbagai macam manfaat dari penggunaan media ini adalah antara lain: dari segi keterampilan berbahasa yang dapat distimulasi melalui permainan ini misalnya kosakata naik-turun, maju mundur, ke atas-ke bawah, dan lain sebagainya. Keterampilan sosial yang dilatih dalam permainan ini di antaranya kemauan mengikuti dan mematuhi aturan permainan, bermain secara bergiliran. Keterampilan kognitif-matematika yang terstimulasi yaitu menyebutkan urutan bilangan, mengenal lambang bilangan dan konsep bilangan. Bahan-bahan yang dapat dijadikan bahan pembuatan media ini yaitu antara lain:

a. Kertas manila polos.

b. Penggaris.

c. Tinta, baik tinta spidol ataupun tinta printer jika kita membuat petak permainan dengan komputer.

d. Spidol warna-warni.

e. Dadu (bisa beli atau membuatnya sendiri).

f. Bidak/maskot digunakan anak.

g. Kartu pertanyaan (kita sesuaikan dengan tujuan pembelajaran). 
Langkah-langkah Penggunaan Media Ular Tangga "Jejak Petualang” adalah sebagai berikut.

a. Bagilah siswa ke dalam beberapa kelompok. Setiap kelompok terdiri dari 3-4 orang peserta dengan 1 orang wasit.

b. Sebelum permainan dimulai, jelaskan bahwa mereka akan bermain ular tangga "Jejak Petualang" dan tanyakan apakah mereka pernah bermain permainan tersebut.

c. Berikan setiap kelompok 1 set mainan ular tangga "Jejak Petualang" terdiri dari petak permainan, kartu pertanyaan, dadu dan beberapa maskot atau bidak.

d. Jelaskan pada mereka mengenai aturan main.

e. Dalam penentuan pemain pertama, pemain kedua, pemain ketiga dan seterusnya ditentukan lewat undian atau melakukan "hom pim pah".

f. Pada gilirannya, pemain melempar dadu dan dapat melangkahkan bidak atau maskotnya beberapa petak sesuai dengan angka hasil lemparan dadu.

g. Pemain yang mendapat angka 6 dari pelemparan dadu, maka pemain tersebut mendapatkan kesempatan sekali lagi untuk melemparkan dan melangkahkan bidaknya lagi.

h. Semua pemain memulai dari petak nomer 1 .

i. Bagi pemain yang turun ataupun naik masing-masing mendapatkan pertanyaan yang memiliki kualitas soal berbeda. Pertanyaan bagi anak yang turun, maka diberikan pertanyaan yang mudah. Sedangkan bagi anak yang naik mendapatkan pertanyaan yang sulit. Mengapa? Hal ini dikarenakan jalan pintas yang akan ditempuh. Jikalau anak tidak dapat menjawab maka anak tetap di dalam petak tersebut.

j. Pemenang dari permainan adalah pemain yang terlebih dahulu mencapai tujuan.

k. Langkah terakhir adalah berilah reward kepada anak yang telah bermain dengan baik.

Kelebihan dan Kekurangan Media Permainan Ular Tangga "Jejak Petualang” dijelaskan berikut ini. Kelebihan media ini sebagai berikut:

a. Media ular tangga ini sangat efektif untuk mengulang (review) pelajaran yang telah diberikan

b. Media ini sangat praktis dan ekonomis serta mudah dimainkan.

c. Dapat meningkatkan antusias anak dalam menggunakan media pembelajaran ini.

d. Anak akan menjawab pertanyaan dengan sungguh-sungguh apabila mereka berhenti di kotak pertanyaan.

e. Media ini sangat disenangi oleh anak karena banyak terdapat gambar yang menarik dan full colour.

Kelemahan media ini adalah:

a. Dimungkinkan menimbulkan kejenuhan karena banyaknya pertanyaan yang akan ditemui anak.

b. Akan menimbulkan kejenuhan pada anak yang menunggu giliran permainan.

c. Keadaan kurang terkontrol akibat kurangnya pengawasan guru dalam proses permainan. 
d. Tanpa pengawasan yang intensif dari guru, anak dapat mudah terjebak dalam permainan ular tangganya saja tanpa bisa menyerap nilai-nilai atau tujuan digunakan media pembelajaran ini.

e. Media ini tidak cocok digunakan untuk kelas dengan jumlah anak/ siswa yang besar.

\section{PENUTUP}

Media merupakan suatu perantara untuk mencapai tujuan pembelajaran. Penggunaan media yang tepat dapat menunjang keberhasilan dalam proses pembelajaran. Hal ini akan lebih mempermudah bagi guru dan siswa dalam mencapai tujuan pembelajaran. Seperti yang kita ketahui media pembelajaran itu banyak macamnya. Untuk proses belajar mengajar yang baik kita harus menggunakan media pembelajaran yang tepat. Oleh karena itu guru harus dapat memilih media yang sesuai dengan bahan pembelajaran sehingga tujuan pembelajaran dapat dicapai dengan baik dan lancar.

Salah satu contoh media yang interaktif, kreatif dan edukatif untuk usia anak dini yaitu media permainan Ular Tangga "Jejak Petualang". Permainan digunakan untuk penciptaan suasana belajar dari pasif ke aktif, dari kaku menjadi gerak (akrab), dan dari jenuh menjadi riang (segar). Media ini diarahkar jar tujuan belajar dapat dicapai secara efisien dan efektif dalam suasana gemb meskipun membahas hal-hal yang sulit atau berat.

\section{DAFTAR PUSTAKA}

Kustandi, Cecep dan Bambang Sutjipto. (2011). Media Pembelajaran Manual dan Digital. Bogor: Ghalia Indonesia.

Sumantri, Mulyani dan Johar Permana. (1998). Strategi Belajar Mengajar. Jakarta: Depdikbud.

Susilana, Rudi dan Cepi Riyana. (2007). Media Pembelajaran Hakikat, Pengembangan, Pemanfaatan, dan Penilaian. Bandung: CV Wacana Prima. 